\title{
A CASE STUDY
}

\section{State of agribusiness management education in India}

\section{SHOJI LAL BAIRWA, UDHAV PRASAD SINGH AND V. KAMALVANSHI}

Received : 14.01.2015; Accepted : 27.03.2015

\begin{abstract}
Agribusiness is a fast growing and market oriented academic discipline due to its high demand in corporate and academic sector across the world. The higher agribusiness education is the solution to problems of meeting the need of agribusiness professionals to farming community and dynamic agribusiness industry. In India, evidence shows that agribusiness faculty is lower than agricultural economics faculty in the colleges and universities. Now, the departments expect more agribusiness faculty to teach more courses for growing student's populations and to maintain research expectations in the agribusiness field. The agribusiness students should develop their strengths in practical and problem solving areas such as team building and interpersonal skills; writing skills and presentation skills. The present study focused on the past, present and future perspectives of agribusiness management education in India. It is also explore the need, importance, present status, curriculum, and challenges of agribusiness management education in India. Lack of teaching faculty, Lack of agribusiness research, Lack of dynamic curricula, and lack of relevant literature are the major obstacles in the development of agribusiness education in India. Indian authorities (ICAR and UGC) can follow the recommendations of National Food and Agribusiness Management Education Commission (NAEC, USA) to develop agribusiness curriculum for master's programme and doctoral degree programme. These recommendations helps to provide a roadmap for educators as they assess their current teaching programs and provide input for further revision of those programs in the future to insure dynamic, vibrant and relevant programs in agribusiness management education. There is a need to critically review the existing agribusiness education system and develop a relevant, flexible, and market oriented agribusiness curriculum and syllabi for master and doctoral programme in India.
\end{abstract}

KEY WORDS : Agribusiness, Higher education, Agribusiness curriculum, Doctoral programme, National agribusiness education commission (NAEC, USA)

How to cite this paper : Bairwa, Shoji Lal, Singh, Udhav Prasad and Kamalvanshi, V. (2015). State of agribusiness management education in India. Internat. J. Com. \& Bus. Manage, 8(1): 126-130.

\section{MEMBERS OF THE RESEARCH FORUM}

Correspondence to:

SHOJI LAL BAIRWA, Department of Agricultural Economics, Bihar

Agricultural University, Sabour, BHAGALPUR (BIHAR) INDIA

Email: smabm.bhu@gmail.com

\section{Authors' affiliations:}

UDHAV PRASAD SINGH, Department of Agricultural Economics, Rajendra Agricultural University, PUSA (BIHAR) INDIA

V. KAMALVANSHI, Department of Agricultural Economics, Banaras Hindu University, VARANASI (U.P.) INDIA 